Original article

\title{
A socio-economic evaluation of a protected area - A case study: Hamadan
}

province, Iran

\author{
Haniyeh Moradpanah ${ }^{1}$, Mohammad Dehdar Dargahi², Soleiman Mohammadi Limaei*3, \\ Monireh Moradpanah ${ }^{4}$
}

${ }^{1}$ Islamic Azad University, Lahijan Branch, Lahijan, Iran

2Department of Environment, Islamic Azad University, Lahijan Branch, Lahijan, Iran

${ }^{3}$ Deptartment of Forestry, Faculty of Natural Resources, University of Guilan, Sowmeh Sara, Iran

${ }^{4}$ Faculty of Environment and Energy, Islamic Azad University, Science and Research Branch, Tehran, Iran

E-mail address (*corresponding author): limaei@guilan.ac.ir

\section{ABSTRACT}

The aim of this study was to investigate the socio-economic issues of a protected area and participation of the local stakeholders in conservation of the protected area. This study was conducted at 7 villages in Hamedan province in the midwest part of Iran. A questionnaire was used for data collection. Reliability of the data was determined by Cronbach's alpha. In order to investigate the relationship between the average incomes of different villages, a t-statistic test was used. Results indicated that at the 0.05 significance level, there were significant differences between most villages. Furthermore, the results indicated that there was no significant relationship between mean income of Jara and Saadat Abad villages. In order to investigate the interest for the preservation of different villages, a t-statistic test was used. Results indicated that at the 0.05 significance level of, there were significant differences between Shademaneh and Maloosan, Siyah Dare and Gheshlagh Najaf, Shademaneh and Taemeh, Taemeh and Gheshlagh Najaf villages. Results also showed that the Maloosan village has the highest income in the area and willingness to participate in conservation activities was highest at this village. The results of this study show a new approach to the protection of biodiversity of protected areas with connection to economic, biological and humanistic studies.

KEY WORDS: protected area, local stakeholders, Morgan test, socio-economic evaluation

ARTICLE HISTORY: received 28 January 2016; received in revised form 11 March 2016; accepted 17 May 2016

\section{Introduction}

Human usage of natural resources can sustain or destroy ecosystem capacity. At the 1992 Earth Summit, the governments of the world agreed on a new agenda for sustainable development. This agenda included a bold new Convention on Biological Diversity (CBD) which, inter alia, called on governments to establish systems of protected areas and to manage these in support of conservation, sustainable use and equitable benefit sharing. Governments recognized protected areas as economic institutions which have a key role to play in the alleviation of poverty and the maintenance of the global community's critical life-support systems. This new vision for protected areas requires an awareness and an understanding of the economic values generated by protected areas (PHILIPS, 1998).

Recently, due to the increase in resource degradation in Iran, the authorities are seeking to protect undisturbed or less disturbed nature zones. However the selection of these protected areas was initially based on the context of land use planning, but there were conscious efforts to protect the last remains of biodiversity in order to be able to keep their natural features in the current unstable development process (MAJNOUNIAN, 2002). Common source and competition for goods and services as well as weak enforcement of laws governing their use may lead to resource degradation (MUTENJE ET AL., 2011). 
Despite the lack of a budget for the conservation and recognition of natural resources, financial resources must be invested wisely (JONATHAN ET AL., 2012). The relationship between the population and communities located within and on periphery of the protected area has caused life stream and activities that to be tied with the protected area from various aspects, and this is in conflict at least with the most basic goal of protected areas which is a ban hunting and providing a secure environment for protected animals and birds. Therefore, from the standpoint of the Department of the Environment's conservation objectives, the current status of human consensus relationship and interaction with the area does not have a very positive and constructive aspect in order to create suitable and sustainable conditions for survival, growth and reproduction of protected plant and animal species. Natural resource management is a complex issue. This involves numerous stakeholders with various demands and groups. Basically, stakeholder participation is an important issue in protected areas. Different groups of stakeholders have different perceptions of nature (BILlGREN \& Holmen, 2008).

Although one way to preserve rural cultural landscapes involves establishing protected areas, management often forgets, or even restricts, the traditional rural activities that have contributed to the high conservation values recognized in these areas (SCHMITZ ET AL., 2012). The resource of protected areas is recognized as an economic institution that plays an important role in reducing poverty and preventing the global society crisis and as the life-support system. This new landscape requires an awareness and an understanding of the economic values of protected areas. Determining the local stakeholders' income may cause to preserve and support the protected areas (PHILLIPS, 1998).

The importance of protected areas is emphasized by international conventions and programmes such as the CBD, the World Heritage Convention (WHC), the Ramsar Convention on Wetlands, the UN Law of the Sea Convention, UNESCO's Man and the Biosphere (MAB) Programme of the United Nations Educational, Scientific and Cultural Organization (UNESCO) and the global programme of WCPA. Together these agreements and programmes are the backbone of international policy on the establishment and management of protected areas for biodiversity conservation and the sustainable use of natural and cultural resources (PHILIPS, 1998).

Despite the prevalence of protected areas, evidence of their impacts on people is weak and remains hotly contested in conservation policy.
A key question in this debate is whether socioeconomic impacts vary according to social subgroup. Given that social inequity can create conflict and impede poverty reduction, understanding how protected areas differentially affect people is critical to designing them to achieve social and biological goals. Understanding heterogeneous responses to protected areas can improve targeting of management activities and help elucidate the pathways through which impacts of protected areas occur (GURNEY, 2015).

Identify/develop and evaluate a range of methodologies and tools for assessing the social impacts of protected areas that enable conservation policy and practice to better adhere to the globally accepted principle that protected areas should strive to contribute to poverty reduction at the local level, and at the very minimum must not contribute to or exacerbate poverty (IUCN-TILCEPA, 2010).

This study aims to investigate the socioeconomic issues of a protected area and determine the income as well as participation of the local stakeholders in conservation. The results may help the conservation and maintenance of biological diversity, natural and cultural resources as well as management of the region.

\section{Materials and methods}

\subsection{Study area}

Maloosan protected area is located in the Karkheh catchment under the Gamasyab subcatchment and in the hydrological unit of Nahavand-Shivan. This area is located in Hamadan province in Iran and this province has various climates from dry to wet climate in plain zones and highlands, respectively. This weather situation exists due to the crossing of Zagros Mountains from the southern areas. The total area of Maloosan protected area is 9513 ha. This protected area has particular plant species such as mint, hawthorn, wild lucerne etc. There are also avian species such as white stork, white-tailed sea eagle, buzzard, etc. as well as mammals such as ram and ewe, hyena, bat etc. Therefore, it makes the importance of the region crucial for conservation (IRANIAN ENVIRONMENTAL PROTECTION AGENCY, 2013a). The stakeholders around and within the protected area and activities such as overgrazing, agriculture and hunting activities, etc. have caused serious damage to the region.

Maloosan protected area has a mountainous landscape, valleys and abundant shelter is located $24 \mathrm{~km}$ northwest of Nahavand city. The longitude is $48^{\circ} 18^{\prime} \mathrm{E}$ and latitude ranges from $34^{\circ} 42^{\prime} \mathrm{N}$ to $34^{\circ} 42^{\prime} \mathrm{N}$. The condition of vegetation cover, water 
resources and climatic conditions of the area provide a suitable habitat. In 1994 a ban on hunting was announced in the region and was promoted to a protected area in 2010 (Fig. 1). There are 12 springs, with various flow rates, in the area the most important springs are called Dozakh Dare, Lisab, Ismail Khani, Dare Bid and Monak. In fact, this region has the lowest water shortage problems among the areas of the province (IRANIAN ENVIRONMENTAL PROTECTION AGENCY, 2013b).

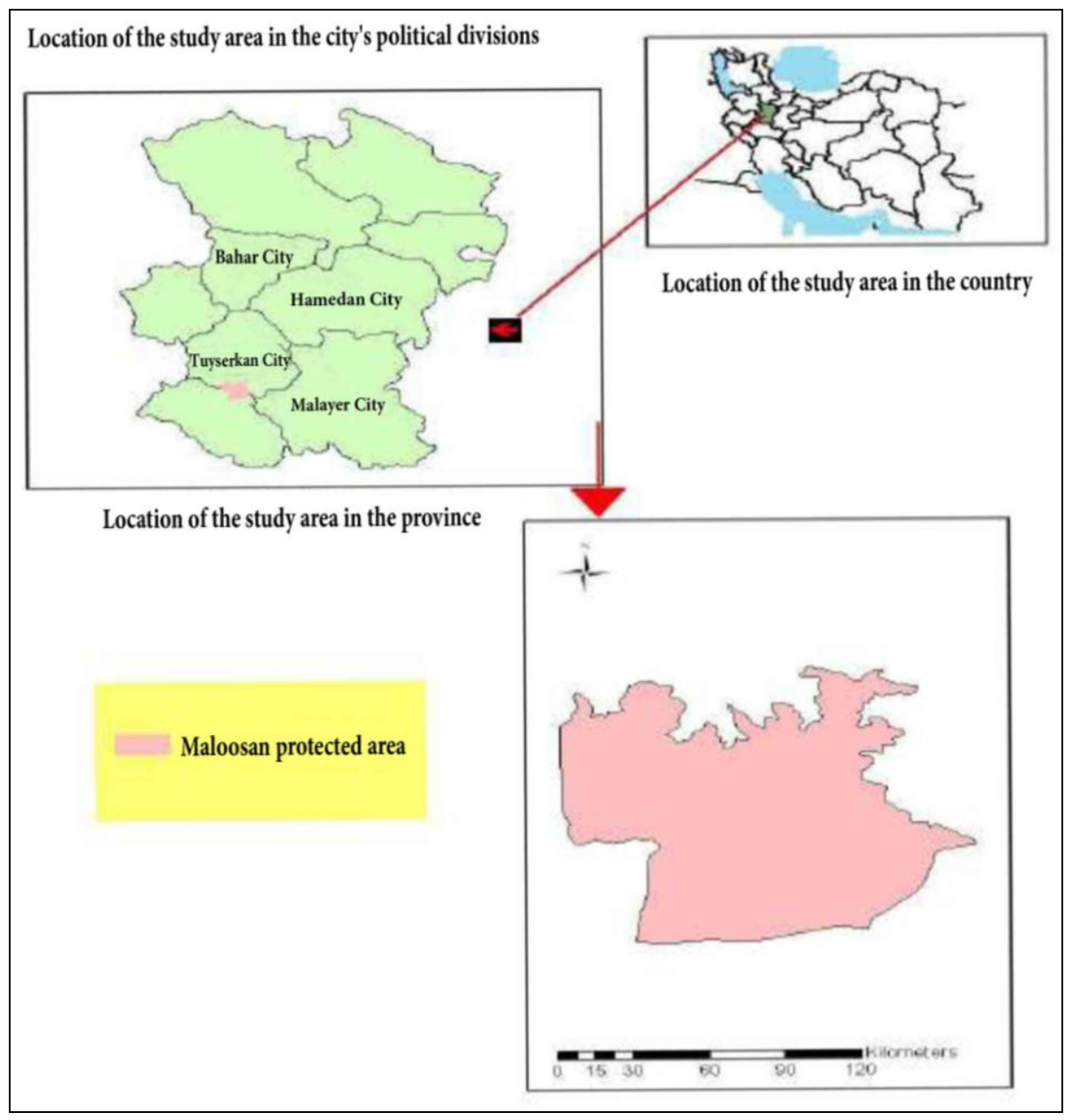

Fig. 1. The position of the Maloosan protected area in Hamadan province (Iranian Environmental Protection Agency, 2013c)

Identification of area promotion to the protected area by Iranian Department of Environment is as follows:

- Official Advertisement No. 1-6406 dated 09.10.1994 prohibiting hunting for three years from the date of 23.09.1994

- Extending the hunting ban for five years from 29.09.1997.

- Extending the hunting ban for five years from 29.09.2001.

- Extending the hunting ban for five years from 21.11.2008.

\subsection{Social status of the area}

There are two settlements (Siyah Dare and Shademaneh) within the Maloosan protected area. Furthermore, there are also settlements of Gheshlagh Najaf, Taemeh, Jara, Saadat Abad and Maloosan in the margin of the study area. The most populous age group belongs to age class of 15 to 64 years which includes 2351 people. The most sparsely populated age groups belong to the age class of 65 years and more (Table 1 ).

Table 1. Population of villages in the study area

\begin{tabular}{|l|c|c|c|c|c|c|c|}
\hline Village name & Jara & Saadat Abad & Taemeh & Shademaneh & Gheshlagh Najaf & Siyah Dare & Maloosan \\
\hline Population & 875 & 154 & 660 & 156 & 233 & 76 & 565 \\
\hline
\end{tabular}




\subsection{Method}

In this study in order to determine the local stakeholders' income in Maloosan protected area, the area, botany and zoology maps were studied. First of all, we have visited the area in order to have some concept of the study area in terms of population distribution, living conditions and socio-economic issues. A questionnaire was designed based on field observations. The Morgan table was used in order to determine the number of questionnaires required (sample size) and the numbers of questionnaires were determined for each village. Therefore, 355 questionnaires were determined for distribution in the study area. According to the Morgan table for villages with a low population, fewer questionnaires were distributed. However, to ensure the results had more accuracy, 55 questionnaires more than the standard limit were distributed.

In order to determine the impact of local stakeholders' income in the conservation of the Maloosan protected area, we considered 2 villages within the area (Shademaneh, Siyah Dare) and 5 villages in the margin of the study area (Maloosan, Taemeh, Gheshlagh Najaf, Saadat Abad, Jara).

The questionnaire contained two sections. The first part involved the socio-economic situation of the protected area with questions such as age, sex, marital status, indigenous status, occupation, educational level, household size and income level. The second part of the questionnaire included questions such as number of livestock, location of livestock grazing (inside or outside the protected area), number of days that livestock graze inside the protected area, annual income of livestock, area of farms that is located inside the protected area, annual land and agricultural products that are produced inside the protected area, water consumption, hunting, medicinal plants, beekeeping, fishing and any kind of exploitation of the area such as the harvesting of timber, sand, tourists entering to the region, salary of environment guards and mining. The parameters were assessed in each village and then extended to the entire protected area.

In order to carry out the research, the area was visited twice. Each visit lasted one week. The first phase was conducted in the late winter of 2013. At this stage, the area was visited and a general figure for the study area was obtained. The population statistics of every village was obtained from the Statistics Organization of Iran, and the maps of botany, zoology and pedology were investigated. Then, the questionnaires were designed as was previously mentioned.
410 questionnaires were distributed only among the men as heads of households. 35\% of respondents were aged between 20 and 30 years, and their jobs were rancher and farmer (farmer or gardener). These people are the most frequent users of the protected area. Most respondent's family size was 3 to 6 persons and a few families had more than 9 members.

The water supply source of most of the villages is from wells. Taemeh village with $75 \%$ for the largest percentage of well use and Siyah Dare with $61.53 \%$ have the greatest source of subterranean water and Gheshlagh Najaf with $57.14 \%$ has more water supply than springs.

In the second phase of visits to the area which took place in the early summer of 2013, questionnaires were distributed. The results were analyzed using SPSS software. The t-test was used in order to compare the village populations.

The analysis of the questionnaires was done in 4 stages:

Stage 1: Examining the village status with separation of income sources.

Stage 2: Comparing the income in each village with a desire to conserve and contribute to the area protection.

Stage 3: Determining the ratio of income in each village to Maloosan protected area.

Stage 4: Comparing the village incomes with each other and comparing their willingness to engage in conservation.

\section{Results}

\subsection{The status of livestock in the area}

In the first phase, the livestock statuses in the area were assessed in each village separately, and then the income from animal husbandry and livestock products was extended to the entire region. Results indicated that the average months of grazing livestock in the protected area was 6 months, average number of livestock daily entering into the protected area was 8699 . The average income from livestock and livestock products for each family was 360 Iranian million Rials and average income from livestock and livestock products was 13690 Iranian million Rials.

Results indicated that the Shademaneh and Sadat Abad villages have the highest and lowest numbers of livestock, respectively. The main occupation of most of the people in Shademaneh village is animal husbandry and the proceeds from the sale of livestock products is mostly from wool and milk and the average income for each sheep is 1861000 Iranian Rials and the average 
income for each calf is 13500000 Iranian Rials. The average annual income from livestock and livestock products for each family for each village has been estimated.

\subsection{The distance of each village from the protected area}

The distance of each village from the protected area is an important factor when using this area for animal grazing. Therefore, Shademaneh and Siyah Dare villages which are located within the protected area have the highest share to use the area. The village of Jara which is located $3 \mathrm{~km}$ away from the protected area is the greatest distance away from it and less affected by animal grazing. The livestock spend less time (months) during the year in the protected area when the livestock owners live in the villages further away from the protected area (Table 2).

Table 2. Duration of livestock grazing in the protected area

\begin{tabular}{|c|c|c|c|c|c|c|c|}
\hline Village name & Maloosan & Taemeh & Siyah Dare & $\begin{array}{c}\text { Gheshlagh } \\
\text { Najaf }\end{array}$ & Shademaneh & $\begin{array}{c}\text { Saadat } \\
\text { Abad }\end{array}$ & Jara \\
\hline $\begin{array}{c}\text { Distance to the } \\
\text { protected area }\end{array}$ & $500 \mathrm{~m}$ & $500 \mathrm{~m}$ & $\begin{array}{c}\text { Within the } \\
\text { area }\end{array}$ & $100 \mathrm{~m}$ & $\begin{array}{c}\text { Within the } \\
\text { area }\end{array}$ & $1 \mathrm{~km}$ & $3 \mathrm{~km}$ \\
\hline $\begin{array}{c}\text { Number of months } \\
\text { area used for } \\
\text { grazing }\end{array}$ & 6 & 8 & 9 & 7 & 9 & 4 & 3 \\
\hline
\end{tabular}

\subsection{The status of garden and agricultural land in} the area

First of all, the income from horticultural products in 7 villages were calculated separately around and within the area. Income from one garden was 25 to 30 million Iranian Rials, while the garden has no product in the first 3 years and spraying and harvesting costs must be paid. The main products were walnuts, peaches and apricots. The village of Maloosan, with an area of 45 ha and an annual production of 1125 tons has the largest area and the highest income. The village of Shademaneh, with an area of 2.5 ha and 62.5 tons of products has the lowest garden area as well as income. Income gained from horticultural crops was 22750 (million Iranian Rials). The total harvested horticulture products from the protected area were 1935 tons and the total garden area in the study area was 91 ha. Furthermore, the total income of agricultural land in the protected area is shown in Table 3.

Hunting activities are prohibited within the protected area. However, local people are allowed to hunt only in the margins of the protected area twice a week (Thursday and Friday) and each time they are allowed to hunt 5 different birds. The quebec bird species is mostly hunted in this area. Hunting is more for entertainment and is not a steady source of income in this area. Frequent calls to the Environmental Monitoring Station when people hear gunshot or approaching to hunt animals shows that people have good contacts with the Environmental Monitoring Station in the area. This indicates that the maintenance and preservation of the area is especially important for the local people. The income from hunting is almost identical in all villages except for the village of Saadat Abad which has the lowest income and also the lowest levels of hunting.

Table 3. The total income of agricultural land in the protected area

\begin{tabular}{|c|c|c|}
\hline $\begin{array}{c}\text { Income from the agricultural crops } \\
\text { (million Iranian Rials) }\end{array}$ & $\begin{array}{c}\text { Total harvested products from the } \\
\text { area (tons) }\end{array}$ & Agricultural land area (ha) \\
\hline 3400 & 534 & 151 \\
\hline
\end{tabular}

\subsection{Sources of lateral income}

The use of medicinal plants is not considered as a source of income. The collection of plants in the village is mostly done by women. Beekeeping in the area is dispersed and done by some households. Fishing only occurs in the River Sarab near the village of Maloosan and in recent years. Due to low levels of water in the river, fishing has also declined. Carp are caught by spear fishing. Fishing is not considered as a job for local people in this area and is not considered as a main source of income (Table 4). 
Table 4. Source of lateral income in the study area

\begin{tabular}{|c|c|c|c|c|c|c|c|}
\hline Lillage name & Maloosan & Taemeh & Siyah Dare & $\begin{array}{l}\text { Gheshlagh } \\
\text { Najaf }\end{array}$ & Shademaneh & $\begin{array}{l}\text { Saadat } \\
\text { Abad }\end{array}$ & Jara \\
\hline $\begin{array}{c}\text { Hunting } \\
\text { (million Iranian Rials) }\end{array}$ & 10 & 10 & 10 & 10 & 10 & 7 & 10 \\
\hline $\begin{array}{c}\text { Medicinal plants } \\
\text { (million Iranian Rials) }\end{array}$ & 70 & 70 & 20 & 60 & 60 & 50 & 10 \\
\hline $\begin{array}{c}\text { Beekeeping } \\
\text { (million Iranian Rials) }\end{array}$ & 70 & 70 & 20 & 60 & 60 & 50 & 10 \\
\hline $\begin{array}{c}\text { Fishing } \\
\text { (million Iranian Rials) }\end{array}$ & 0.8 & 0 & 0 & 0 & 0 & 0 & 0 \\
\hline
\end{tabular}

3.5. Comparison of the amount of income in each village with a desire to conserve and contribute to conservation in the area

At this phase, the average income of each village was determined followed by the highest and lowest income for each village (Table 5). Two questions were also asked from the village residents; the first question asked about their views and level of interest in environmental conservation in the area (Table 6), and the second question assessed the extent of their participation in the implementation of conservation projects in case of an infringement to the wildlife (Table 7).

Table 5. Annual income of different villages in the study area

\begin{tabular}{|c|c|c|c|c|c|c|c|}
\hline Village name & Maloosan & Siyah Dare & $\begin{array}{c}\text { Gheshlagh } \\
\text { Najaf }\end{array}$ & Shademaneh & Taemeh & $\begin{array}{c}\text { Saadat } \\
\text { Abad }\end{array}$ & Jara \\
\hline $\begin{array}{c}\text { Annual income } \\
\begin{array}{c}\text { Average annual income } \\
\text { (million Iranian Rials) }\end{array}\end{array}$ & 480 & 420 & 420 & 281.9 & 330.8 & 100 & 100 \\
\hline $\begin{array}{c}\text { Maximum income } \\
\text { (million Iranian Rials) }\end{array}$ & 980 & 800 & 800 & 730 & 710 & 180 & 150 \\
\hline $\begin{array}{c}\text { Lowest income } \\
\text { (million Iranian Rials) }\end{array}$ & 230 & 70 & 70 & 80 & 60 & 70 & 70 \\
\hline
\end{tabular}

Table 6. Willingness to protect the environment in the study area [\%]

\begin{tabular}{|c|c|c|c|c|c|c|c|}
\hline Village name & Maloosan & Siyah Dare & Taemeh & Shademaneh & $\begin{array}{c}\text { Gheshlagh } \\
\text { Najaf }\end{array}$ & $\begin{array}{c}\text { Saadat } \\
\text { Abad }\end{array}$ & $\begin{array}{c}\text { Jara } \\
\text { Willingness to protect }\end{array}$ \\
\hline Very high & 94.6 & 78.4 & 78.4 & 78.4 & 62.2 & 59.5 & 51.4 \\
\hline High & & 21.6 & 21.6 & 10.8 & 13.5 & 29.7 & 40.5 \\
\hline Low & 5.4 & - & - & - & 24.3 & 10.8 & 8.1 \\
\hline Very low & - & - & - & 10.8 & - & - & - \\
\hline
\end{tabular}

Table 7. Participation in conservation, reaction of local people against hunting of wildlife [\%]

\begin{tabular}{|c|c|c|c|c|c|c|c|}
\hline $\begin{array}{c}\text { Village name } \\
\text { Conservation } \\
\text { participation }\end{array}$ & Maloosan & Siyah Dare & Taemeh & Shademaneh & $\begin{array}{c}\text { Gheshlagh } \\
\text { Najaf }\end{array}$ & $\begin{array}{c}\text { Saadat } \\
\text { Abad }\end{array}$ & Jara \\
\hline $\begin{array}{c}\text { Preventing the } \\
\text { hunters from the } \\
\text { hunting the wildlife }\end{array}$ & 29.7 & - & 24.3 & 18.9 & 48.6 & 56.8 & 40.5 \\
\hline $\begin{array}{c}\text { Inform the } \\
\text { Environmental } \\
\text { Monitoring Station }\end{array}$ & 40.5 & 54.1 & 59.5 & 48.6 & 40.5 & 37.8 & 32.4 \\
\hline $\begin{array}{c}\text { Informing the hunters } \\
\text { for the importance of } \\
\text { wildlife }\end{array}$ & 10.8 & - & 16.2 & 24.3 & 10.8 & & 18.9 \\
\hline $\begin{array}{c}\text { Do not care about the } \\
\text { hunting at the } \\
\text { protected area }\end{array}$ & 18.9 & 45.9 & - & 8.1 & - & 5.4 & 8.1 \\
\hline
\end{tabular}


3.6. The ratio of the income of each village to the total income of the protected area

The ratio of the income of each village to the total income of the protected area was estimated and this ratio was compared with the willingness of individuals to preserve. Results indicated that the villages with higher incomes from the area, such as Maloosan, were more willing to protect the area and to participate in conservation projects (Table 8).

Table 8. Ratio of income in each village in the study area

\begin{tabular}{|c|c|c|c|c|c|c|c|c|}
\hline Village name & Maloosan & $\begin{array}{c}\text { Siyah } \\
\text { Dare }\end{array}$ & Taemeh & Shademaneh & $\begin{array}{c}\text { Gheshlagh } \\
\text { Najaf }\end{array}$ & $\begin{array}{c}\text { Saadat } \\
\text { Abad }\end{array}$ & $\begin{array}{c}\text { Jara } \\
\text { The entire } \\
\text { area }\end{array}$ \\
\hline $\begin{array}{c}\text { Amount of income in } \\
\text { each village from the } \\
\text { whole area } \\
\text { (million Iranian Rials) }\end{array}$ & 18120 & 15680 & 12410 & 10390 & 5260 & 3950 & 3910 & 69750 \\
\hline $\begin{array}{c}\text { Percentage of each } \\
\text { village income from } \\
\text { the whole area [\%] }\end{array}$ & 26 & 22 & 18 & 0 & 8 & 6 & 5 & 100 \\
\hline
\end{tabular}

\subsection{Comparison of the income between villages}

In order to investigate the relationship between average incomes of different villages, a t-statistic test was used. The t-test assesses whether the means of two groups are statistically different from each other. This analysis is appropriate whenever you want to compare the means of two groups. Results indicated that at the 0.05 significance level of, the $\mathrm{t}$-statistic value $(\mathrm{t}=1.96)$ was more than its critical value between the following villages: Shademaneh and Maloosan, Maloosan and Taemeh, Taemeh and Siyah Dare, Siyah Dare and Gheshlagh Najaf, Gheshlagh Najaf and Jara, Shademaneh and Taemeh. Therefore, $\mathrm{H}_{0}$ is rejected and its hypothesis will be accepted. Thus, it can be concluded that the average incomes of villages are not equal and are significantly different. Furthermore, the results indicated that there is no significant relationship between the mean incomes of the villages of Jara and Saadat Abad which means the $\mathrm{H}_{0}$ hypothesis is accepted.

\subsection{Evaluation in the level of interest in the preservation of the environment in villages}

In order to investigate the interest in the preservation of the environment between different villages, a t-statistic test was used. Results indicated that at the 0.05 significance level of, the t-statistic value $(t=1.96)$ was more than its critical value in the following villages: Shademaneh and Maloosan, Siyah Dare and Gheshlagh Najaf, Shademaneh and Taemeh, Taemeh and Gheshlagh Najaf. Therefore, $\mathrm{H}_{0}$ is rejected and the hypothesis will be accepted. Thus, it can be concluded that the average level of interest in conservation is not equal between the villages and has a significant difference in willingness to participate in the conservation of the area.
In addition the results indicated that there were no significant relationship in the preservation interest between the following villages and the $\mathrm{H}_{0}$ hypothesis is accepted: Maloosan and Siyah Dare, Gheshlagh Najaf and Jara, Maloosan and Taemeh, Jara and Saadat Abad.

\section{Discussion}

This study was conducted in 7 villages (2 villages inside the protected area and 5 villages around it) in Hamedan province, Iran. The aim of this study was to investigate the socio-economic issues of a protected area and to determine the income as well as the level of participation in conservation of the local stakeholders. The results show that there are significant differences between most villages in the terms of their average income in the protected area. Results also show that interest in protecting the area is significantly different between some of the villages.

CAMPBELL ET AL. (2013) investigated the socioeconomic impacts of marine protected areas in Indonesia. They showed that policies, laws and regulations can improve the social welfare of beneficiary communities in protected areas. There is only a need to provide appropriate economic and legal and partnership incentives. A similar result was also obtained in this survey.

XU ET AL. (2013) in a study which was conducted in Mekong, where the ecological indicators were investigated (soil, vegetation cover and fauna). The local stakeholders' opportunity costs in protected areas were investigated and their impacts on conservation were measured. The socioeconomic status and income of local stakeholders were investigated. The results showed that structural and functional biodiversity had been reduced, habitat fragmentation had increased, 
carbon sequestration in natural forests had been reduced, and hydrological systems altered.

HARVARD (1995) investigated socio-economic impacts of protected areas in Uganda. The sample population was 84 households. The impact on people's income on the distance from the protected area has been measured. The number of households in this research was between 2884 people and 739 households, and the survey was done among all the people of the villages, and also the impact of income, in addition to the village distance from the protected area, and the income with the level of willingness to protect the area has been studied. While the Harvard study was conducted on the national parks, forest areas, and hunting ban areas.

EMERTON (1996) investigated the environmental evaluation of forest resources in Kenya. The agricultural land and the amount of harvested crops was ignored and eventually it was concluded that the amount of income has little connection with the area. While our research, considered agricultural land and gardens, the amount of harvested products was also investigated, and its association with the conservation area was expressed.

We can conclude that this study would help the policy makers and in this case the Iranian Environmental Department should consider the socio-economic impacts of villages at the protected area and also the willingness of the local people to participate in any projects related to environmental protection.

\section{References}

Billgren Ch., Holmen H. 2008. Approaching reality: Comparing stakeholder analysis and cultural theory in the context of natural resource management. Land Use Policy, 25: 550-562.

Campbell S.J., Kartawijaya T., Yuliantoa I., Prasetiaa R., Clifton J. 2013. Co-management approaches and incentives improve management effectiveness in the Karimunjawa National Park, Indonesia. Marine Policy, 41: 72-79.

Emerton L. 1996. Participatory Environmental Valuation: Subsistence Forest use around the Aberdares, Kenya. Applied economics conversation discussion paper, No 1, ACE-DP-1.

Gurney G.G., Pressey R.L., Cinner J.E., Pollnac R., Campbell S.J. 2015. Integrated conservation and development: evaluating a community-based marine protected area project for equality of socioeconomic impacts. (Theme issue 'Measuring the difference made by protected areas: methods, applications and implications for policy and practice' compiled and edited by R. L. Pressey and P. J. Ferraro). Philosophical Transaction of Royal Society B. (370)1681.

Howard P. 1995. The Economics of Protected Areas in Uganda: Costs, Benefits, and Policy Issues. M.Sc. thesis, Univ. of Edinburgh, Edinburgh, Scotland.

Iranian Environmental Protection Agency, 2013a. The management plan of Maloosan protected area, wildlife report (unpublished reports).

Iranian Environmental Protection Agency, 2013b. The management plan of Maloosan protected area, erosion report (unpublished reports).

Iranian Environmental Protection Agency, 2013c. The management plan of Maloosan protected area, land use report (unpublished reports).

IUCN-TILCEPA, 2010. Joint PAEL-TILCEPA workshop on Protected Areas Management Evaluation \& Social Assessment of Protected Areas. Gland, Switzerland: IUCN. 17 pp.

Jonathan M., Green H. 2012. Estimating management costs of protected areas: A novel approach from the Eastern Arc Mountains, Tanzania. Biol. Conserv., 150: 5-14.

Majnounian H. 2002. Protected areas management plan instructions, Publications of Management and Planning Organization, Publication No. 257.

Mutenje M., Ortmann G. 2011. Management of non-timber forestry products extraction: Local institutions, ecological knowledge and market structure in South-Eastern Zimbabwe. Ecol. Econ., 70: 454-461.

Philips A. 1998. Economic Values of protected Area Guidelines for protected Area Managers, World Commission on Protected Areas (WCPA). Cardiff University, UK.

Schmitz M.F. 2012. Effects of a protected area on land-use dynamics and socioeconomic development of local populations. Biol. Conserv., 149: 122-135.

Xu J., Grumbine R.E. and Beckschäferc P. 2013. Landscape transformation through the use of ecological and socioeconomic indicators in Xishuangbanna, Southwest China, Mekong Region. Ecol. Indicators, 36: 749-756. 